\title{
Placing Movers: An Overview of the \\ Asian-Pacific Migration System
}

Jon Goss and Bruce Lindquist

\author{
We do not wear upon our sleeve \\ That damaging star of shame \\ But need we symbols to believe \\ We're Jews in all but name? \\ RAYMOND PILLAI, “LABOURER'S LAMENT"
}

\footnotetext{
C
} Conventional wisdom has it that contemporary international movements of labor are quantitatively and qualitatively distinct from those of the past, and that the "scale and diversity of today's migrations are beyond any previous experience" (UNPF 1993, 6). A "new age of migration" has arisen, in which the international movement of workers has never been as pervasive, or as socioeconomically significant, as it is today (Castles and Miller 1993, 260). In this "new age of migration," the Asia-Pacific is the "newest international migration system" (OECD 1992), accounting for perhaps 35-40 percent of the four to five million workers who cross national borders each year (Hernandez and Tigno 1995, 547).

Certainly the origins and destinations of international migration change over time, and in this paper we use the useful heuristics of "ages" and "systems" to define historical periods and dominant patterns in international labor flows. There are broadly three historical periods in the AsiaPacific region - the age of indenture, the period of guest workers, and the era of contract labor. In the contemporary era an "Asia-Pacific migration system" is emerging (Massey and others 1998, I60), where a system is defined as groups of countries that exchange labor and have "feedback mechanisms, reciprocity and linkages between migration and other flows - not only of people ..., but also of capital, goods, ideas and information" (Hugo I996, I07). This system is composed of three subsystems: Asia-Middle East (the movement of contract workers from South and

The Contemporary Pacific, Volume I2, Number 2, Fall 2000, 385-4I4

(C) 2000 by University of Hawai'i Press 
Southeast Asia to the oil-producing countries); Southeast Asia-East Asia (the movement of contract and illegal workers from developing countries of Southeast Asia and East Asia to the newly industrializing economies of those regions; and the Pacific system (the movement of Pacific Islanders to countries of permanent settlement).

Focusing on temporal discontinuities and spatially specific flows, however, distracts attention from persistent structural processes that underlie the production and reproduction of a global labor reserve. In some cases, for example, contemporary contract labor migration is remarkably similar to historical forms of indenture, and patterns of movement can only be explained as the effect of political-economic relationships and cultural compatibility, themselves often a legacy of migrations in the past. In the excited rush to proclaim "the new," there is a danger of ignoring significant continuities in the formation of the global labor reserve. Given population growth over the last few decades, the proportion of the world's population on the move in the second half of the twentieth century has remained more or less constant (Martin 1997, 3), and contemporary migration is dwarfed absolutely by the historic trans-Atlantic and transPacific flows of the late nineteenth and early twentieth centuries (Potts I990, 7I). With two-thirds of the world's working population living in Asia and the Pacific, and extreme intraregional inequalities in socioeconomic opportunity, it is remarkable that these two regions do not account for more movement (Martin I997).

The dynamics of international labor migration have been recently described in terms of a "migration transition" whereby industrialization and shifts in domestic labor demand affect the balance of immigration and emigration of labor (Martin 1994). Evoking the now discredited stage models of economic development, this concept is based on the generalization of observed "turning points" in the recent migration experience of European countries-Italy, for example, was an important source of labor for western European economies until the mid-I970s, but has subsequently become a destination for international migrants from developing countries, including sixty thousand Filipinos (Abella I995b). According to this model, "labor migration is a normal part of economic development" (Abella I995a) as workers are displaced from traditional agriculture and "emigration pressure" builds up to spill over borders if there is a pattern of established transnational relationships (Martin 1994). Subsequent economic growth and fertility decline gradually produce tight labor markets in some sectors, such that, in an intermediate stage, developing countries export some types of labor but import others-as do Malaysia, 
Korea, and Thailand at present. Once they have reached advanced stages of development, and are over the "migration hump," they become laborimporting countries like Japan, Taiwan, Hong Kong, and Singapore.

Palau at first sight appears to fit into the transition stage-it now hosts perhaps six thousand overseas contract workers (75 percent Filipino), while about five thousand Palauans ( 30 percent of the national population) live overseas (Sudo I997, 2). However, this small island society and dependent economy is surely not industrializing, and it seems unlikely the emigration of Palauans will reverse despite the demand for labor. Most Asia-Pacific countries are both source and destination of different types of labor, as labor markets are not only differentiated into sectors, but also by ethnicity, class, gender, and nationality. Also, what this economistic model recognizes as a contingency- "if there is a pattern of established relationships"-has everything to do with conditions creating relative demand and supply, which are largely structured by differential rates of capital penetration and the processes of uneven development that have taken place over centuries, not decades (Potts I990, 6). Descriptive and determinist models cannot explain how, within the generalized production of a global labor reserve, regional and bilateral systems develop and remain distinctive, that is, how labor market differentials are translated into selfsustaining migration networks and institutions (see R Cohen I995, 3).

Understanding the particularism of international migration requires a comparative historical approach, and we begin this paper with a brief review of three stages in Asia and the Pacific, together with a description of the three contemporary subsystems in the region. Our purpose is to highlight some of the continuities, and particularly the role of uneven development, segmented labor markets, social networks, and migrant institutions. An explanation of international labor migration focusing on dual labor markets and networks follows. We argue that concepts of citizenship and native entitlement, together with discriminatory practices that depend on the operation of national borders, effectively put the lie to Marx's famous predictions of the progressive elimination of unfree labor, for it remains an intrinsic part of capitalist development ( $\mathrm{R}$ Cohen I995, 2). Nevertheless, even if migrants originally envisage movement as a temporary sojourn, as they organize in resistance to the conditions of unfree labor and to improve living conditions in the host country, and as transnational community develops, they may develop commitment to permanent residence and abandon goals of returning to the source country. As one observer commented ironically, "there is nothing more permanent than temporary workers" (Martin I994, 4). 


\section{A Brief History of International Labor Migration in the Asia-Pacific Region}

The international movement of labor has been "a fundamental component of capital accumulation since the beginning" (Sharma 1997, I3), and merchants scouring Asia and the Pacific recruited, pressed, or enslaved workers to gather products, extract natural resources, and operate their vessels, often exploiting precapitalist social relationships in the process. However, the institutional organization of labor migration did not begin until the mid-nineteenth century, when the commodity boom generated a demand for labor to meet absolute shortages in the plantations and mines of colonial territories. The first phase of international labor migration, the age of indenture, lasted roughly from I 830 to I940. Although most indentured workers eventually returned to their homelands, their legacy is significant minorities who have formed ethnic communities in host countries and often continue to influence patterns of immigration. The second phase, from 1940 to 1970 , is the period of government-sponsored guest workers, when international migration rates were generally lower. Contract labor and illegal migrants moved to meet relative labor shortages in Europe and the Pacific Rim "settler societies" (the United States, Canada, Australia, and New Zealand), primarily from colonies and postcolonial societies within their proximate spheres of influence. There was also some movement from Asia, primarily the consolidation of earlier flows of indentured workers, many of whom settled and contributed to the creation of multicultural societies. The contemporary period, from 1970 onward, can be described as the era of contract labor, with large-scale commercialized movement of labor to the Middle East and the newly industrializing economies of Asia from developing countries in South and Southeast Asia. Although rates of illegal migration are high, and many migrants overstay, most migrants presently return home. During this period, permanent movements from Asia and the Pacific for family reunion in the settler societies have increased, in some cases producing a political backlash against minorities in multicultural societies.

\section{The Age of Indenture}

During the age of indenture, workers were exported from labor-surplus agrarian societies of Asia and the Pacific to plantations and mines in labor-deficit territories, where a reliable and cheap source of labor was the precondition for the capitalist production of primary commodities. 
Indenture took a variety of forms, typically articulating with indigenous social relations, but generally was a contractual arrangement with penal sanctions whereby workers agreed to passage to and employment in a foreign country under specified terms, usually for five to ten years. Recruiting laborers from subsistence economies under expectation of their return was a means by which surplus value could be transferred geographically, whereby the rural societies of Asia and the Pacific subsidized the costs of the social and physical reproduction of labor to capital in the metropolitan cities.

The first indentures in the Pacific were for sugar plantations, and workers were often recruited from existing sandalwood labor gangs. Between I 840 and I9I5, over three hundred thousand Islanders were indentured and some tens of thousands more or less enslaved (McCall and Connell I993, 2-3; Munro I990a, li). Melanesians, and some Micronesians, were recruited to sugar plantations in Fiji, to copra plantations in Sāmoa, New Caledonia, and French Polynesia, and to nickel mines in New Caledonia. Typically, labor flows took place between colonial territories, such that, for example, the British brought Melanesians from the Solomons and the New Hebrides (Vanuatu) to Fiji, while the Germans recruited from Papua and New Guinea to Western Sāmoa.

As a result of the effects of European diseases on indigenous populations, their perceived unsuitability or resistance to wage labor, and in some cases a paternalistic desire to protect their way of life, planters in the Pacific turned to Asia for workers during the commodity booms in sugar in the I880s and copra in the I9Ios (Leckie I990, xxxii). About I.5 million Indians were indentured in total, including 6I,000 to Fiji from I 879 to I9I6 (Tinker I974). Many workers were recruited through the kangani system, where an established laborer was licensed to return home to recruit a "crew," typically drawing on kinship and traditional social relations (Potts I990, 79). In China, emigration was technically illegal under Chinese law, but British agents in treaty ports recruited 500,000 Chinese laborers (Ong I995, 53), including 56,720 to Hawai'i (I 852-I 899), 6,984 to Sāmoa (I903-I934), I, I00 to Tahiti (I865-I867), and 6,000 to German New Guinea (I885-I9I4). The practices of indenture in China were notoriously brutal, and unknown numbers of coolies were "shanghaied." Large numbers of Chinese also emigrated independently under the "credit-ticket" system, whereby travel was financed by advances from kin or commercial moneylenders (Leckie I990, xxxiii).

In Japan, the dislocation of the countryside and the growth of large 
port cities subsequent to the Meiji restoration led to government-sponsored emigration to relieve unemployment and poverty. Between I868 and I942, about 800,000 Japanese workers and their families went overseas to work, principally to Hawai' $i$ and the United States mainland between I890 and I910 (231,000 and 107,000 respectively). Smaller numbers were deployed throughout the Pacific in the late nineteenth century, to work in New Caledonia's nickel and Tahiti's phosphate mines, and as sugar workers and pearl divers. In addition, 2 million settled in the overseas territories of East Asia-Manchuria $(270,000)$, Korea $(753,000)$, and Taiwan $(397,000)$-and the Pacific (Okunishi I995, I39). Labor deployment was an important aspect of Japan's desire to expand its influence in the "south seas," particularly Micronesia, during the nan'yō period (I 880-I945). Beginning modestly with small trading posts, Japanese firms ultimately established successful plantations and factories dependent on a well-coordinated flow of Japanese immigrants, primarily families, living in large-scale settlements. By 1942 the Japanese population in Micronesia $(96,000)$ exceeded the number of Micronesians. In Palau, Japanese government investment in agricultural settlements and the fishing industry brought a flood of immigrants and triggered a building boom in the harbor town of Koror, transforming the small settlement into a thriving port and colonial capital (Peattie I988, I74). In I938, the Japanese population in Palau reached I $_{5}, 000-$ more than double the indigenous population. Defeat in World War II ended the nan'yō period, with most of the Japanese settlers evacuated during the war, and those remaining repatriated immediately afterward.

Japanese labor was recruited by small-scale independent agents, the imin-kaisha, but regulated under legislation passed in I 894, and the government subsidized recruitment from I92 I (Shimpo I995, 49). At the same time, an I 899 imperial decree forbade all foreigners from working in most economic sectors (Potts 1990, I 5I); nevertheless large numbers migrated from China and Korea. Japan provides an early, but long-lived example of the apparently contradictory and supposedly temporary situation of simultaneous labor export and import.

Recruitment patterns varied over time as government policies shifted, as workers organized on the basis of ethnic identity, and as hostility mounted between migrants and indigenous populations. The changing patterns of recruitment in Hawai' $i$, for example, were due to the planters' strategy of countering labor organization within the existing ethnic workforce (Beechert I993); similar colonial "race-making" occurred in the Pacific 
Islands: for example, Javanese became the preferred indentured labor in New Caledonia after I 86I because they were found to assimilate relatively easily and, unlike Chinese and Japanese, did not compete with French business interests after their contracts expired (Willson, Moore, and Munro I990, 87).

Ironically, the very characteristics that made them ideal coolies-their values of hard work, individual sacrifice, and collective endeavor-became a distinct disadvantage to colonial authorities when indentured workers settled permanently and moved into trade (Ong I995, 52). Restrictions were placed on Chinese trading activities, for example, in Kiribati, Tahiti, and Papua New Guinea, and on the Japanese in New Caledonia, Hawai'i, and Sāmoa. Many Indian migrants to Fiji were motivated by prospects of claiming land so that only 40 percent of the so-called girmitiyas took up the free passage home; their successful participation in the economy has produced a long-standing cultural resentment that informed the coup d'état in 1987 .

Indentured laborers had diverse individual circumstances and motivations for migration, but common to all of the migration flows was the development of recruitment systems that incorporated existing social networks into new institutions, often promoted and regulated by governments. These institutions were also adapted by migrants in order to establish and maintain a presence in the host country. Large numbers recruited family members and spouses, and exploited opportunities to settle, engage in trade, and purchase property, ultimately establishing attachment to place and rights to residence in the new land.

\section{The Period of the Guest Worker}

Indenture was progressively eliminated, beginning with Malaysia in I 878 and finally dying with the Dutch administration of the East Indies in I94I, as a combination of several circumstances, including opposition to its abuses by labor organizations and liberal metropolitan governments, restrictions imposed by nationalist governments in the labor-surplus countries, decreasing commodity prices due to war and depression, and technological innovations that progressively made the labor-intensive plantation form of production obsolete. The mass movement overseas of millions of marginalized peasants in Asia slowed dramatically.

Meanwhile, relative shortages of labor in the settler societies and Europe led to the import of unskilled workers from selected sources. The bracero program was introduced in the United States in 1942 to meet 
shortages in agriculture, which had been slow to improve productivity and so paid low wages. The European guest-worker programs beginning in the I960s attracted hundreds of thousands of unskilled agricultural, service, and industrial workers from neighboring southern European countries and former colonies. The scale in the Pacific settler societies was altogether smaller, but New Zealand, for example, began importing unskilled contract labor from Western Sāmoa, the Cook Islands, Niue, and Tokelau, supplemented in the I960s with agricultural workers from Fiji and Tonga (Sudo I997, 3; Crocombe 1974). Here, as in the case of Mexican migrants in the United States and gastarbeiter in Germany, even after contract labor migration has stopped, migrant networks continue to supply illegal workers, asylum seekers, and family members petitioning for reunion. Designed to provide a short-term solution to sectoral labor shortages, guest-worker programs develop into self-sustaining flows that prove politically and economically costly to control. The introduction of "family reunion" preferences, for example, has generally backfired: though originally conceived as a means to meet labor needs and continue the process of nation-building by increasing European stock, instead Asian and Pacific Islanders have taken advantage of the program (Macura 1994, 2; Reimers 1983). As Sassen has pointed out, patterns in international migration are all too often the unintended consequence of ill-conceived policy (I996).

While selectively promoting migration of unskilled workers, and authorizing family reunion, developed countries also encouraged migration of "PTK" workers (professional, technical, and kindred), who were expected to assimilate into the native middle class. Postwar prosperity in OECD countries led to an increased demand for personal services and a shortage of professionals, particularly in health care. Racially specific immigration policies were replaced with occupational quotas allowing recruitment of professionals, such as doctors and nurses, raising the serious issue of the "brain drain," that is, the loss of highly qualified and productive workers embodying significant investments of human capital: in other words, the geographical transfer of value in human form. This problem exemplifies the potential contradiction between individual and collective interests, where migration is rational for the individual, but may not benefit society as a whole. In developing countries, educational programs ostensibly to their benefit introduce "western, primarily US, material and technology into their economic and educational systems," ultimately producing a surfeit of professionals and technical labor (Liu I995, 256).

The complex combination of race and class in migration policy is well 
illustrated by the case of New Zealand, which long recruited unskilled Pacific Islanders, but which has relatively low levels of family reunion (Rod and Williams I996, 35). New Zealand liberalized immigration policy in 1986, but was faced with so many Pacific Islanders taking advantage of free entry that the program was abandoned the same year and a new points system made migration for unskilled Islanders almost impossible. Skilled workers from Asia, on the other hand, are warmly welcomed as part of New Zealand's Asia 2000 policy, and the government promotes entrepreneurial and professional immigration from Hong Kong, Taiwan, and Korea. Controversy has erupted since some of these migrants have established households in the settler society, and thereby gained rights to education for their children, but have returned to their original employment or business (Skeldon I994). Although there are only small numbers of these "astronauts," media attention reinforces the negative stereotypes of economic migrants as opportunists exploiting the generosity of the host society. Ironically, if the segmentation of colonial labor markets led to the development of ethnically marked "entrepreneurial minorities," such as the Chinese, in the Pacific-Asia region, this pattern is being repeated as ethnic enclaves are created in settler societies, where the Chinese again, for example, are confined to a narrow range of professional occupations and business activities (Massey and others I998, I 82).

\section{The Era of Contract Labor Migration}

Rates of international migration were relatively low in the immediate postwar years, but increased rapidly with the development of commercial contract migration to the Middle East in the I970s, and to Asia's newly industrializing economies in the I980s (see Athukorala I993, 30).

The migration of workers to the Gulf is the largest of the contemporary international labor migrations, with an average of over one million workers deployed annually from the mid-I970s to the present. The oil-rich states exhibit extreme labor shortages in highly segmented labor markets as a result of the very low national labor force participation, and access of nationals to government employment and nonlabor income (see Alegado and Finin, this issue). Asian workers are reliable and cheap and, unlike other Arab nationals who might invoke ethnicity to support demands for better treatment and are more likely to migrate with families, they are clearly temporary aliens unlikely to challenge the authority and monopoly of wealth enjoyed by the ruling elites of the Gulf states (Gardezi I995).

Recruitment originally followed long-established social networks, the 
kangani again operating in South Asia, so that almost half of India's overseas contract workers originate from the state of Kerala, and the majority of Bangladeshis come from four eastern regions (Lim I994, I3I). However, sources were rapidly diversified, in part the result of government policies to avoid dependence on particular sources, motivated again for reasons of political control, and in part as a consequence of the commercialization of recruitment (Alburo 1994, 56). Elasticity of supply of Asian labor was ensured by the khafeel system, whereby a government-franchised labor recruiter is issued bloc visas, typically on the basis of political patronage, and workers are effectively bonded for the length of their contract (Abella 1994, I69). Remarkably reminiscent of indenture, the movement of labor is again motivated primarily by agents rather than individuals, and the laborer has become an international commodity (Sassen 1988,50 ).

Migration within East and Southeast Asia has increased dramatically in the past decade or so as the newly industrializing economies have sought cheap overseas labor to meet sectoral labor shortages created by rapid economic growth and exacerbated by declining fertility and slowed expansion of domestic labor forces. At the same time, rapidly developing export industrializing economies of Southeast Asia, such as Thailand, Malaysia, Indonesia, and particularly the Philippines, began to officially promote the export of labor overseas. While economic integration has facilitated the flow of goods and capital throughout the region, the newly industrializing economies have pursued increasing automation, relocation of labor-intensive manufacturing overseas, and repatriation of targeted ethnic groups overseas in order to reduce the flows of unskilled labor. Since the early I980s, however, serious labor shortages have occurred in "nonexportable" sectors - those industries where capital is not footloose due to "some necessary or preferred geographical fixedness" (Gibson and Graham 1986, I34), most obviously agricultural production, construction, retail, personal services, and entertainment-and the Asian newly industrializing economies began to head "down a guest worker path" (Martin 1997, 9).

Newly industrializing Asian economies still exhibit low levels of foreign labor absorption compared with western capitalist economies at similar levels of development (Martin I997, 2), ${ }^{1}$ principally for political reasons. In countries such as Japan, Korea, Taiwan, and Malaysia-committed to nationalist development goals and with political systems very different from settler societies - national identity is constructed through powerful ideologies of indigenousness, whereas Singapore, for example, is con- 
cerned to preserve a delicately balanced multicultural society (see Macura I994, I7I). ${ }^{2}$ Although structurally dependent on foreign labor in lowwage sectors of the economy, in these countries migration is effectively disguised in the form of training and education (Skeldon I998, 39), or denied in the form of illegal migrants who are implicitly encouraged by poor policing and inadequate detection, at least while their services are needed (Hugo 1995, 397). Singapore has probably the most restrictive labor market in the world, and since 1979 it has systematically sought to discourage labor migration through its corrective high wage policy, improved labor productivity, relocation of manufacturing overseas, numerical restrictions, and taxes designed to eliminate marginal savings on employment of foreigners. It has attempted to expand the national labor force by offering citizenship to professionals, favoring those of Chinese ancestry. Foreign workers constituted I 8 percent of the workforce in I994, but they are denied accompaniment of family members and face no prospect of legal permanent settlement, even through marriage to Singaporeans (cited in Freeman and Mo I996, I64). Similarly restrictive, Japan encourages repatriation of overseas Japanese rather than immigration, but an estimated 300,000 illegal workers are in the country, including female workers in entertainment and the sex industry and unskilled male labor in shipyards and industrial production, as well as 63,000 "students" and I7,000 "trainees," most of whom work (Okunishi I995, I39; Quibria I996, 9I). In these cases nationalism and ethnocentrism sustain a vital supply of cheap and flexible labor, as governments effectively condone the operation of exploitative and sometimes criminal recruiting systems, thereby displacing the costs of labor migration and the long-term costs of the reproduction of labor power onto migrants and their source countries.

Two countries ostensibly illustrative of the migration transition are South Korea and Malaysia, in the sense that they are simultaneously importers and exporters of labor. The Korean government has promoted overseas labor migration under bilateral agreements since the late I960s, and construction companies established a unique pattern of project-tied migration under turnkey contracts in Vietnam during the war there and subsequently in the Middle East. Despite resistance from unions, in I99 I Korea began legally admitting foreign workers under government-sponsored technical training programs (Newman I995). The 30,000 or so trainees, however, remain a small proportion of the estimated I00,000 foreign workers, and the difference is made up by illegal migrants. In contrast, Malaysia is a country of largely spontaneous labor emigration, supplying 
approximately 250,000 overseas workers, the vast majority to Singapore, but also large numbers of construction workers to East Asia and a small number of professionals to the settler countries (Rod and Williams I996, 26). Simultaneously, there are 563,000 legal foreign workers in Malaysia, the majority (70 percent) from Indonesia, but a significant minority (20 percent) from the Philippines, most of whom are in Sabah, with the balance from Thailand ( 5 percent), Pakistan, and Bangladesh (Athukorala I993, 40). These workers are hired to meet labor shortages in plantations (3I percent), construction (29 percent), and domestic service (I 8 percent), but they also use these "revolving doors" to establish informal enterprise or obtain more lucrative employment. In all, perhaps as many as a million illegal migrants have come from Indonesia, following paths from Flores to Sulawesi to Sabah, and from North Sumatra or Java to peninsular Malaysia (see Hugo I995). Indonesian Muslims have easily obtained residency and citizenship, enjoying rights denied to 850,000 ethnic Chinese and Indians who have lived most of their lives in the country (Lim I994, I39). However, recent protests and government concern that the new Indonesian minority emerging in enclaves of Malaysian cities presents a national security threat led to the launch of Operation Go Away in 1998 (M Cohen I998, I6).

One of the first countries to officially promote and regulate overseas contract migration was the Philippines. The Corporate Export Strategy introduced in 1979 gave tax breaks and other incentives to Philippines construction companies recruiting labor for work on contracts overseas, and the government formally took up trade in human services in I980, entering into a series of bilateral agreements with various labor importers. The Philippine Overseas Employment Administration, founded in 1982, promotes and regulates labor export and attempts to protect and represent migrant workers, a contradictory role made increasingly impossible by the scale of the phenomenon and the expansion of informal and illegal recruitment. By 1993 an estimated 6 million Filipinos were working overseas in 130 different countries, of whom 4I percent were legal contract workers, 30 percent undocumented workers, and 29 percent settlers (Gonzalez and Holmes I996, 301).

Initially, most overseas workers were seamen or construction workers, but there has been a dramatic increase in service workers, now the largest category ( 35 percent), which is 90 percent female (Torres I996, 39). Half (49 percent) of the Philippines overseas workers are women, and Filipinas 
outnumber Filipinos I 2 to I in Asian destinations (Fernandez I994, 82). Similar striking increases in female participation occur in Indonesia, where the ratio of female to male migrants went from I:I.4 in 1983 to $3.4: \mathrm{I}$ in I988 (Lim and Abella I994, 228). ${ }^{3}$ Although not a new feature of international migration-for example, as many as two hundred thousand women were recruited as karayuki-san prostitutes to work in Japan's overseas territories (Douglass and Roberts 2000; cf Warren 1993)-female contract labor raises special concerns. Most women migrants are entering the labor force for the first time (Asis I995, 22I), and their inexperience, coupled with the fact that many engage in "hidden" work as domestic helpers or "entertainers," makes them particularly vulnerable to abuse.

The movement of Filipino workers to the Pacific has been described as "the last wave of labor migration from Asia" (Connell I990b, I 28), although it is probably only the latest, given the expanding potential labor reserve in China and Indochina. ${ }^{4}$ Beginning in the I950s, Filipinos were contracted on military bases in Guam, which was often perceived as a stepping-stone for migration to the United States, and they now account for more than 25 percent of the total population of about $\mathrm{I} 45, \mathrm{O}, \mathrm{O}$. Smaller numbers, but higher proportions, of Filipinos are found in the Northern Marianas, perhaps 16,000 Filipinos out of a workforce of 37,000. Filipinos have also migrated to Papua New Guinea since 1974, when they were recruited to meet shortages in the government sector (mostly teachers and nurses), and more recently they have moved into mining and logging. Filipino workers in Palau number more than 3,500 of a population of $\mathrm{I} 8,000$ and provide construction labor as well as service workers in the tourist industry and domestic helpers (Alegado and Finin, this issue).

Theories of international migration rarely consider the case of the Pacific Islands despite persistent and extensive circulation and small-island depopulation that characterize the so-called South Pacific system (Hayes I99I; Hau'ofa I987). Regional specialists tend to divide the Pacific experience into three empirical categories, determined by cultural-geographical features, such that Polynesia is characterized by international migration to metropolitan countries of the Pacific rim, Melanesia by internal migration, and Micronesia by both patterns, together with increasing receipt of international labor migrants (Connell I990a, I). ${ }^{5}$ Polynesians are said to be "highly migration oriented" (Hayes I99I, 2) and in smallisland societies migration "dominates and defines the social structure, it is a matter of central pre-occupation for individuals and it constitutes a 
dominant theme in the cultural and symbolic structures of the societies" (Patterson 1987, I25). In general, migration in the Pacific is explained as "an ancient islander characteristic" (McCall and Connell I993, 4).

The notion of timeless movement obscures the political-economic dynamic that produces historically specific dislocations in life chances that motivate international migration, and it accounts for neither increased mobility over the last three decades or so, nor the specificity of flows within and between Pacific Island territories and the Pacific rim settler societies. World systems theory has been systematically applied to the Pacific, however, most notably by John Connell, who argued that "migration is primarily a response to real and perceived inequalities in socio-economic opportunities that are themselves a result of dependent and/or uneven sectoral and regional development, a function of the penetration of capitalism into this global periphery" (I990a, 3 ). The role of the state in perpetuating dependency and international migration is acknowledged in the concept of MIRAB societies, where migration generates remittances, and aid finances local bureaucracy to provide most sources of income and employment (Bertram and Watters I985). Other accounts note that neocolonial institutions prepare Islanders, in terms of both abilities and expectations, for occupations not available in their homelands (see Ward I997, I 82).

Still, the prime focus is on the social relations of migration, such that movement is considered a peculiar adaptation of the kinship mode of production to global capitalism. The individual emigrant is conceived as part of a single organic community characterized by bilocality of its members distributed over home territories, other Pacific states that act as "staging camps" for further migration, and metropolitan countries (Crocombe I974, 8). Over 400,000 Pacific Islanders live overseas-I70,000 in New Zealand, I 50,000 in the United States; 85,000 in Australia; I7,000 in Canada; 22,000 in France-distributed in what Gerard Ward has called pan-Pacific "anastomosing patterns," that is, in spatially extensive corporate networks that channel flows of capital, labor, goods, and information (I997, I 86). They operate what Bertram and Watters called "a transnational corporation of kin," with members differentially adapted to life in metropolitan and traditional societies $(1985,499)$.

It is estimated that more than a third of the Palauan population resides overseas and maintains extensive networks with the homeland as well as other overseas Palauans. Asang, for example, questions the likely effectiveness of Palau government efforts to lure its overseas residents home 
with promises of satisfying employment because Palauan migration is deeply embedded in social and cultural norms. Despite their migration to different geographic locations, "Palauanness" is preserved through "the social tapestry that both encourages and regulates migration" (Asang, this isssue).

The three components of the putative Pacific-Asia "international migration system" are said to be structured in rather different fashions: Asia and the Middle-East by the dynamics of labor supply and demand and the changing fortunes of economic development; the Pacific by cultural predispositions and the constant limitations of geographical scale. Hopefully, comparative research will progressively undermine the essentialism as well as the economic and cultural determinism that sustains such conceptions.

\section{Explanations of LABOR Migration}

Explanations of the contemporary patterns of international labor migration are diverse and contradictory, the literature characterized by "a variety of competing theoretical viewpoints fragmented across disciplines, regions and ideologies" (Massey, Arango, and Taylor 1994, 700). Nevertheless, lurking in dominant accounts of the cumulative increase in postwar migration are two general and related factors: increased individual mobility as a result of technological advances in transportation, and progressive integration of the world economy as a result of globalization. As a result, Castles and Miller, for example, argued that the nation-state should no longer be the primary spatial unit for studies of migration (1993, 275), and Hayes that Pacific migrant societies bring into "question the applicability of the nation-state concept to socioeconomic analysis in the context of large-scale international migration" (I99I, 22-23).

Improvements in international travel can hardly be gainsaid, but many migrants continue to make their way by foot on forest trails and by small vessels_into Malaysia and Thailand, for example-and for most unskilled migrants, international travel for work is often arduous, hazardous, and expensive. International labor migration is hardly as simple a matter as boarding a plane, and in the majority of cases movement is not an individual enterprise, but involves numerous agents and institutions. Similarly, while ongoing transnationalization and deterritorialization of production, and integration of cultural institutions, have effected a relative decline in the political and economic capacity of the state vis-à-vis 
international capital, these forces have not necessarily led to an erosion of the effects of sovereignty and international borders for unskilled workers. The border plays a vital role in the reproduction of the international labor reserve, as it functions to segment national labor markets and control foreign labor recruits (Douglass and Roberts 2000). In a nontrivial sense, international labor migration can only occur across international boundaries: legal and institutional frameworks maintain differential labor markets, while state agencies manage labor immigration and emigration subject to domestic politics, often lurching from promotion of migration and even tolerance of illegal labor flows to virtual closure of borders and hostile clampdowns (Martin, Mason, and Tsay I995, I I7).

If technological changes have increased mobility for some migrants, they have also enhanced the capacities of most states to restrict, regulate, and repatriate others (Gould and Findlay I994, 278). Even as restrictions are removed on the transnational flows of capital, information, and services, when it comes to the international trade in labor, "we see the national state claiming all its old splendor and asserting sovereign right to control its borders and to grant citizenship" (Sassen I996, 9). More so in Asia and the Pacific, since while the rest of the world develops economic pacts and trade agreements to pursue integrated economic development, this region is "taking care of business" through the increasing volume and complexity of capital and labor flows (ILO I992, 48).

Linkages between countries resulting from movements of capital (whether as direct foreign investment or bilateral aid), international trade, and media are important in opening up "transnational space" for the circulation of labor (Lim and Abella I994, 209). Foreign capital investment in particular may lead to the proletarianization of the labor force and incorporate workers into the labor reserve (Sassen 1988). As Sharma noted, "it appears that as capital flows into a county, labor begins to flow out and conversely, as capital flows out . . (im)migrant labor begins to flow in" (I997, 3I). This occurred historically with capital penetration of the countryside under colonialism and the displacement of the millions of peasants who became urban migrants or indentured workers, but is also apparent in contemporary Southeast Asia where offshore investment by East Asian capital accompanies flows of workers from Malaysia, Thailand, Indonesia, and the Philippines. Significantly, the recent economic crises in the region have produced "Asia's new jobless," a large reserve army moving in and out of temporary, low-wage employment unprotected from unscrupulous and abusive employers, and victims of smuggling rings and corrupt officials (Economist, 28 Mar 1998). 
If economic dislocation provides the "push factor" for international labor migration, the "pull factor" is income opportunity provided in the segmented labor markets of destination countries (Piore I986, 24). According to the dual-labor-market theory of international migration, in developed countries, workers in capital-intensive industries are effectively treated as part of "capital": invested with education and specialized training, and organized into unions that protect their collective rights, they become a fixed factor of production too valuable to lose during periods of low demand. Workers in the secondary sector, however, are dismissed during economic downturns without either capital or the state having to bear the costs of their unemployment. Many of the jobs in the secondary sector are in " $3 \mathrm{D}$ " industries, so-called because the work is difficult, dangerous, and dirty, and wages are depressed by a "structure of expectation" based on a correlation between status and remuneration. National workers generally shun secondary-sector employment, and labor shortages are met by mobilizing reserves only marginally invested in the labor market, traditionally women and youth. Shortages have intensified, however, because of social and demographic changes in the labor market and because services provided by low-wage workers are income elastic so demand increases with economic development (Abella I995a, I27). Overseas labor is the obvious solution because migrants derive their social status from their roles in their home community, and "they are also untouched by the menial, even demeaning, character of the work" (Piore I986, 25).

From this perspective it becomes clear why a university-educated woman from the Philippines is willing to accept a job as a domestic servant overseas: her "migration project" may entail sacrificing high social status at home for a long-term income stream that supports her extended family, still the point of reference for her sense of identity (see Barsotti and Lecchini 1995). Similarly it is clear why "cheap" and "flexible" labor is sought by employers and the national governments of, say, Singapore or Hong Kong (Sharma 1997, 28-29). Most Asian and Pacific destination countries adopt versions of what Freeman and Mo have called the " $3 \mathrm{~s}$ strategy," targeting specific sectors and skill categories of migrants, and admitting these laborers for the short term only (Freeman and Mo I996, I 56). Migrant laborers are cheap because the full costs of the reproduction of their labor power are not borne by national capital and the state, but are partly paid by their kinship groups, communities, regions, and countries of origin (see Sider I992, 232). Flexibility results from lack of protection under labor law, lack of rights to "social wages," and lack of 
citizenship. Evidence suggests that the flexibility to fire workers in response to market conditions is more significant than low wages in decisions to hire foreign labor (Lee and Sivananthiran 1996). Migrant labor is effectively restricted to the secondary sector by the politico-juridical requirements of citizenship and by regulations tantamount to reproducing unfree labor.

Sensational media coverage highlights child and female prostitution in East and Southeast Asia, and "indentured servitude" of laborers transported by notorious and mysterious "Asian gangs" (Lintner I993, 26), but few of the millions of other contemporary contract laborers are fully informed of their rights, and most are encumbered by the baggage of economic and social debt. Information is tightly controlled by recruiting operations that are underregulated and sometimes exploitative. Even officially sanctioned recruits pay placement and other fees, mortgaging property or borrowing from usurers to meet expenses, or receiving advances from agents that will subsequently be deducted from wages (Goss and Lindquist 1995). Even before recruitment, potential migrants must mobilize resources through kinship and other social networks, and young female workers, in particular, may be effectively bonded by filial loyalties to particular employers, forms of employment, and incomes.

Overseas contract workers are tied by strict contracts to particular employers; to a specific type, location, and length of employment; to the form, amount, and currency of compensation; and often to compulsory savings schemes. Their activities in the host country are regulated in terms of entry, exit, and internal travel; membership of worker's associations or unions is denied or restricted; family visits or reunions are prohibited or limited; and rights to petition for legal residency are denied (Sharma I997, I8). The "new age of migration" is, therefore, distinguished by conservation of means by which state and capital preserve cheap and flexible reserve labor.

This is only one side of the story, however, for international labor migrants find ways to resist and subvert these practices, organizing to improve working conditions and remuneration, and to obtain legal residential status, thereby freeing themselves from noneconomic relations of exploitation. Part of their struggle is to reproduce the networks and institutions that link their home and host societies, vital to perpetuating migration as a survival or accumulation strategy, and part is to transform their secondary status in their host societies, to obtain legitimate and long-term residency. 
International migration, once initiated, tends to perpetuate itself in the form of networks, that is, "sets of interpersonal ties that connect migrants, former migrants, and non migrants in origin and destination areas through ties of kinship, friendships, and shared community origin" (Massey and others 1993, 448). Networks originally develop from social relationships mobilized to further individual migration where they function to provide information, access to gatekeepers, and funding for transportation or fees, so reducing the costs and risks of migration. Consequently, "the size of the migratory flow between two countries is not strongly correlated to wage differentials or employment rates, because whatever effects these variables have in promoting or inhibiting migration are progressively overshadowed by the falling costs and risks of movement stemming from the growth of migrant networks over time" (Massey and others I993, 450). Networks have a life of their own, so that by the time immigration controls are imposed it is usually too late to stop the flow (Acevedo and Espenshade I992). So oriented to emigration are the people of Sri Lanka, the Philippines, Pakistan, and Bangladesh, and so well organized their national institutions and informal networks, that Hugo has described them as suffering "emigration fever" (I995, 397).

Networks are not only governed by local norms of reciprocity and sustained by personal contact, however, as they are rapidly penetrated by commercial and bureaucratic relations, and they may make migration more selective and competitive (Goss and Lindquist I995, 330). Kearney spoke of networks as "income-seeking organisms" (I986), and Hugo described an "international migration industry" consisting of state bureaucracies, recruiters, lawyers, migration agents, transport operators, travel agents, and middle persons of various kinds (1996, I08). Overseas migration in Southeast Asia, for example, involves kinship, patron-client relations, and chains of informal brokers-including previous migrants, village headmen, and construction foremen whose recruitment of their personal workforce is remarkably reminiscent of the kangani system (Spaan 1994; Singhanetra-Renard 1992; Lindquist 1993).

Although international recruitment of labor is conceived by governments as a stopgap measure, and migrants themselves view overseas employment as a temporary means to improve their life chances, migration almost inevitably leads to long-term settlement. Neoclassical economic theories predict the progressive equalization of wage differentials through migration, but destination countries become dependent on immigrants who subsidize the costs of domestic production and consumption, 
and source countries become dependent on remittances. Public and private agencies multiply and elaborate in both countries to take a cut of the differential in cost and returns to labor across borders. Migrants too are obviously invested in the reproduction of networks and institutions that facilitate movement, and these in turn may be adapted to sustain bilocality, or transnationalism, spreading the household across borders.

\section{CONCLUSION}

International labor migration is an individual and institutional response to inequalities in life chances produced by the uneven development of capitalism. It is mediated first and foremost by the legal regimes and labor policies of the state, but also by elaborate networks of formal public and commercial agencies and informal agents, and of kinship and traditional sociocultural relationships, all of which combine to transcend geographical distance and political boundaries. Such mediating institutions also provide resources with which migrants might cope with their ambivalent status in the destination, their "betweenness" in the ambiguous social space that defines the intersection of secondary labor markets and nationality.

Central to an understanding of international labor migration is the use of the sovereignty of the state and the bundle of natural rights accorded to citizens to restrict the access of even legal immigrants to the "social" wage, that is human services provided by the local and national state in the form of long-term health care, housing, and education (Rodriguez I996, 32). In the contemporary context of relative labor shortages, the promotion and tolerance of immigration represents a compromise between the needs of capital and the state for cheap labor and the demands of indigenous workers for the protection of native entitlements.

In the settler societies an uneasy tension exists between ideologies of civic pluralism, in which citizenship is defined politically, that is, by allegiance to the state and its symbols of constitution and flag, and nativism, in which citizenship is defined by essential characteristics. This situation permits the naturalization of immigrants independent of race and ethnicity, albeit with some significant restrictions and subject to reversals resulting from resistance by domestic "distributional coalitions" (cited in OECD I992, 63), which in turn raises the specter of a "new nativism" in the United States, particularly in the so-called front-line states such as California (Kearney I99I). In Asia and the Pacific nativism dominates, and indigenousness is typically defined by jus sanguinis (sanguinity), such that rights of citizenship are reserved for citizens and their direct kin. Jus solis 
(place of birth) simply does not apply to ethnic Chinese in Indonesia and Indians in Fiji, for example. In Japan, an official prophecy on the impossibility of foreigners assimilating to its dominant culture is (self-)fulfilled by discriminatory policies that ensure that ethnic Koreans remain secondclass citizens, even after two generations. In Singapore, a potential future problem is prevented by compulsory regular pregnancy tests for unskilled female migrants!

If the states of Asia exhibit a "lingering authoritarianism" that sustains a political will capable of systematic discrimination against minorities, the ultimate question may be one of economics, since guest-worker systems are extremely expensive to maintain - the United States, for example, spends $\$ 3$ billion on immigration control (half of what it spends on all forms of overseas aid). There are also practical problems in enforcing the distinction between temporary and permanent residence, and unskilled and skilled workers, and containing immigrant workers within particular sectors (Martin, Mason, and Tsay I995).

Again, however, this is only one side of the story, for migrant networks seem to have a life of their own, while immigrant associations, business associations, civil rights lobbies, and national government and nongovernment organizations engage in the "battle for the border" (Rodriguez I996). The battle occurs on several fronts, involving struggles for worker and citizenship rights, and for the capacity of working-class and peasant communities to spatially organize social reproduction across international economic space. States are clearly losing the battle historically: fully onethird of the 9 million or so legal immigrants in the United States today were once "temporary" and illegal aliens (cited in Martin 1994, 3), and in an amnesty in Malaysia in 1992, 450,000 Indonesians registered (Lim and Abella I994, 228).

Transnational communities develop from international labor migration not as a necessary outcome, but through collective struggle against the state and institutionalized forms of ethnocentrism and racism that reproduce the reserve of unfree labor. The experience of European and settler societies suggests that the struggle potentially opens up a space for the politics of pluralism and multiculturalism. Asia and the Pacific have very different political ideologies and cultural values, and it may be wrong to assume that they will follow the same path. ${ }^{6}$ Still, these countries, with the possible exception of Singapore, lack the will and capacity to police immigration, and systematically ignore and undermine their own official policies in the interests of economic growth (Cornelius, Martin, and Hollifield I994, 387). Most likely they will not be able to resist the guest- 
worker path, which must surely lead to progressive naturalization and labor freedom. Ultimately, however, this is not a matter for speculation but for political engagement.

\section{Notes}

I There are 3.7 million foreign workers, about 2.7 percent of the total labor force, in seven major Asian immigration countries (Japan, Korea, Taiwan, Hong Kong, Singapore, Malaysia, and Thailand), ranging from less than I percent in Korea and I.5 percent in Japan, to I 6 percent in Malaysia and 2I percent in Singapore, compared with 5-10 percent in the settler societies and Europe (Martin 1997).

2 Contemporary Fiji is similar to Malaysia in this regard: in the former, full citizenship rights belong only to Melanesians, and in the latter only to indigenous Malays (bumiputera).

3 Indonesian regulations encourage female migration by offering greater maximum fees for recruitment of women (Abella 1995b, 245).

4 As many as 0.75 million Chinese have emigrated in recent years, some 200,000 to the United States, 200,000 to Asia, I 50,000 to Russia, and 100,000 to Europe (Hugo I995, 398). A state-owned company promotes labor migration as a solution to economic and political problems. Labor export is expected to expand dramatically in the coming years: "The only question is, how large will it get?" (Saywell I997, 52).

5 Seriously depopulated small islands include Niue, Wallis and Futuna, the Cook Islands, Pitcairn Island, and Tokelau, all of which have a majority of their populations living overseas; high rates of Polynesian migration, particularly to New Zealand and more recently to the United States, occur in the Samoas and Tonga, which have 40 percent and 30 percent of their national populations overseas, respectively; international migration from Melanesia is mostly from Fiji, especially of skilled and semi-skilled ethnic Indians since the 1987 coup; Micronesians migrate from Guam and the Northern Marianas to the US mainland, but these states also receive international migrants, especially Filipinos in construction and tourist services.

6 Martin, for example, speculated on the basis of European and North American experience that permanent settlement and family reunion might lead after two or three decades to an immigrant population of IO-20 percent of the peak migrant worker levels, even in the countries that actively rotate workers and restrict settlement, such as Singapore and the Gulf States, and as high as 50-60 percent of peak migrant levels in countries that progressively expand worker rights $(1997,24)$. 


\section{References}

Abella, Manolo

I994 International Migration in the Middle East: Patterns and Implications for Sending Countries. In International Migration: Regional Processes and Responses, edited by Miroslav Macura and David Coleman, I63-I 8I. Economic Studies, 7. New York: UN Economic Commission for Europe.

I995a Asian Labor Migration: Past, Present and Future. ASEAN Economic Bulletin I2 (2): I $25-\mathrm{I} 35$.

1995b Sex Selectivity of Migration Regulations Governing International Migration in Southern and South-Eastern Asia. In International Migration Policies and the Status of Female Migrants, 24I-252. United Nations.

Acevedo, Dolores, and Thomas Espenshade

1992 Implications of the North American Free Trade Agreement for Mexican Migration into the United States. Population and Development Review I 8 (4): 729-744.

Aguilar, Filomeno V

I996 The Dialectics of Transnational Shame and National Identity. Philippine Sociological Review 44 (I-4): IOI-I36.

Alburo, Florian A

I994 Trade and Turning Points in Labor Migration. Asian and Pacific Migration Journal 3 (I): 49-80.

Asis, Maruja

I995 Labor Force Experience of Migrant Women: Filipino and Korean Women in Transition. In International Migration Policies and the Status of Female Migrants, 22 I-238. United Nations.

Athukorala, Premachandra

1993 International Labor Migration in the Asia-Pacific Region: Patterns, Policies and Economic Implications. Asia-Pacific Economic Literature 7 (2): $28-57$.

Barsotti, Odo, and Laura Lecchini

I995 The Experience of Filipino Female Migrants in Italy. In International Migration Policies and the Status of Female Migrants, I53-I62. United Nations.

Beechert, Edward D

I993 Patterns of Resistance and Social Relations of Production in Hawaici. In Plantation Workers: Resistance and Accommodation, edited by Brij V Lal, Doug Munro, and Edward D Beechert, 45-67. Honolulu: University of Hawai'i Press. 
Bertram, I Geoff, and Ray F Watters

I985 The MIRAB Economy in South Pacific Microstates. Pacific Viewpoint 26:498-5I9.

Castles, Stephen, and Mark J Miller

I993 The Age of Migration: International Population Movements in the Modern World. New York: Guildford Press.

Cohen, $\mathrm{M}$

I998 Deport and Deter. Far Eastern Economic Review, 23 April, I6-I7.

Cohen, Robin

I995 Prologue. In The Cambridge Survey of World Migration, edited by Robin Cohen, I-9. Cambridge: Cambridge University Press.

Connell, John

I990a Modernity and Its Discontents: Migration and Change in the Pacific. In Migration and Development in the South Pacific, edited by John Connell, I-28. Canberra: National Center for Development Studies, Australian National University.

I990b The Last Wave: Filipino Labor Migration to the Pacific. In Labor in the South Pacific, edited by Clive Moore, Jacqueline Leckie, and Doug Munro, I28-I32. Townsville: James Cook University of North Queensland.

Cornelius, Wayne, Philip Martin, and James Hollifield

I994 Japan: The Illusion of Immigration Control. In Controlling Immigration: A Global Perspective, edited by Wayne Cornelius, Philip Martin, and James Hollifield, 375-4I4. Stanford, CA: Stanford University Press.

Crocombe, Ron G

I974 Labor Migration in the Pacific. Geneva: International Institute for Labor Studies.

Douglass, Michael, and Glenda Roberts

2000 Japan in a Global Age of Migration. In Japan and Global Migration: Foreign Workers and the Advent of a Multicultural Society, edited by Michael Douglass and Glenda Roberts, 3-37. London: Routledge.

The Economist

I998 Asia, a New Jobless: The Unwanted. 28 March.

Fernandez, Nena G

I994 Feminization of Philippine Labor Migration. Solidarity I4I-I42: 8 I -85 . Manila. Fortnightly.

Freeman, Gary P, and Jongryn Mo

I996 Japan and the Asian NICs as New Countries of Destination. In International Trade and Migration in the APEC Region, edited by Peter J Lloyd and Lynne S Williams, I56-I73. Oxford: Oxford University Press. 
Gardezi, Hassam Nawa

I995 The Political Economy of International Labor Migration. Montreal: Black Rose Books.

Gibson, Katharyn, and Julie Graham

I986 Situating Migrants in Theory: The Case of Filipino Construction Workers. Capital and Class 29:I3 I-I49.

Gonzalez, Joaquin L, III, and Ronald D Holmes

I996 The Philippine Labour Diaspora: Trends, Issues and Policies. Southeast Asian Affairs, 300-3 I7. Singapore. Annual.

Goss, Jon, and Bruce Lindquist

I995 Conceptualizing International Labor Migration: A Structuration Approach. International Migration Review 29 (2): 317-35 I.

Gould, William T S, and Alan M Findlay

I994 The Geography of the "New" International Migration. In Population, Migration and the Changing World Order, edited by William T S Gould and Alan M Findlay, 275-285. Chichester: Wiley.

Gurak, Doug, and Fe Caces

1992 Migrant Networks and the Shaping of Migration Systems. In International Migration Systems: A Global Approach, edited by Mary Kritz, L Lim, and Hania Zlotnic, I 50-I76. Oxford: Clarendon Press.

Hau'ofa, Epeli

I987 The New South Pacific Society: Integration and Independence. In Class and Culture in the South Pacific, edited by Antony Hooper and others, I-I 2. Suva: Institute of Pacific Studies.

Hayes, Geoffrey

I99 I Migration, Metascience, and Development Policy in Island Polynesia. The Contemporary Pacific 3: $1-58$.

Hernandez, Carolina G, and Jorge V Tigno

1995 ASEAN Labor Migration and Regional Stability. The Pacific Review 8 (3): $544-557$.

Hugo, Graeme

1995 Illegal International Migration in Asia. In The Cambridge Survey of World Migration, edited by Robin Cohen, 397-402. Cambridge: Cambridge University Press.

I996 Asia on the Move: Research Challenges for Population Geography. International Journal of Population Geography 2:95-I I 8.

ILO, International Labor Organization

I992 World Labor Report I992. Geneva: International Labor Organization.

Kearney, Michael

I986 From the Invisible Hand to Visible Feet: Anthropological Studies of Migration and Development. Annual Review of Anthropology I 5: 33I-36I. 
I99 I Borders and Boundaries of State and Self at the End of Empire. Journal of Historical Sociology 4 (I): 52-74.

Leckie, Jacqueline

1990 An Overview of the Pacific Labor Reserve. In Labor in the South Pacific, edited by Clive Moore, Jacqueline Leckie, and Doug Munro, xxvii-xxviii. Townsville: James Cook University of North Queensland.

Lee, Kiong-Hock, and A Sivananthiran

I996 Contract Labor in Malaysia: Perspectives of Principal Employers, Contractors and Workers. International Labor Review I35 (6): 75-9I.

Lim, Lin Lean

I994 International Labor Migration in Asia: Patterns, Implications and Policies. In International Migration: Regional Processes and Responses, edited by Miroslav Macura and David Coleman, I27-I47. Economic Studies, 7. New York: UN Economic Commission for Europe.

Lim, Lin Lean, and Manolo Abella

I994 The Movement of People in Asia: Internal, Intra-regional and International Migration. Asian and Pacific Migration Journal 3 (2-3): 209$24 \mathrm{I}$.

Lindquist, Bruce

I993 Migration Networks: A Case Study from the Philippines. Asian and Pacific Migration Journal 2 (I): 75-IO4.

Lintner, Bertil

1993 Rocks and a Hard Place. Far Eastern Economic Review, 9 September, 26-27.

Liu, J M

1995 A Comparative View of Asian Immigration to the USA. In The Cambridge Survey of World Migration, edited by Robin Cohen, 253-259. Cambridge: Cambridge University Press.

Macura, Miroslav

I994 Overview. In International Migration: Regional Processes and Responses, edited by Miroslav Macura and David Coleman, I-20. Economic Studies, 7. New York: UN Economic Commission for Europe.

Martin, Philip

I994 Migration and Trade: Challenges for the I990s. Working Paper 4.I, Comparative Immigration and Integration Research Group, International and Area Studies. Berkeley: University of California.

I995 Investment, Trade and Migration. International Migration Review 29 (3): 820 .

I997 Labor Migration: What Role Did It Play in the Asian Economic Miracle? Paper presented at Conference on Population and the Asian Economic Miracle, East-West Center, Honolulu, 7-ro January. 
Martin, Philip, Andrew Mason, and Ching-lung Tsay

I995 Overview. ASEAN Economic Bulletin I 2 (2): I I7-I24.

Massey, Douglas, Joaquin Arango, Graeme Hugo, Ali Kouaouci, Adela Pellegrino, and J Edward Taylor

1998 Worlds in Motion: Understanding International Migration at the End of the Millennium. Oxford: Clarendon Press.

Massey, Douglas, Joaquin Arango, Graeme Hugo, Ali Kouaouci, J Edward Tay-

lor, and Adela Pellegrino

I993 Theories of International Migration: A Review and Appraisal. Population and Development Review I9 (3): $43 \mathrm{I}-466$.

Massey, Douglas, Joaquin Arango, and J Edward Taylor

I994 An Evaluation of International Migration Theory: The North American Case. Population and Development Review 20 (4): 699-752.

McCall, Grant, and John Connell

I993 Pacific Islander Migration: Context and Prospects. In A World Perspective on Pacific Islander Migration: Australia, New Zealand and the USA, edited by Grant McCall and John Connell, I-I6. Center for South Pacific Studies, Pacific Studies Monograph 6. Kensington, NSw: University of New South Wales.

Munro, Doug

I990a The Origins of Laborers in the South Pacific: Commentary and Statistics. In Labor in the South Pacific, edited by Clive Moore, Jacqueline Leckie, and Doug Munro, xxxix-li. Townsville: James Cook University of North Queensland.

I990b Transnational Corporations of Kin and the MIRAB System: The Case of Tuvalu. Pacific Viewpoint 3 I (I): 63-66.

Newman, Michael

I995 Help Wanted. Far Eastern Economic Review 2:36-37.

OECD, Organization for Economic Co-operation and Development 1992 Trends in International Migration. Paris: OECD.

Okunishi, Yoshio I995 Japan. ASEAN Economic Bulletin I2 (2): I39-I62.

Ong, J H

I995 Chinese Indentured Labor: Coolies and Colonies. In The Cambridge Survey of World Migration, edited by Robin Cohen, 51-56. Cambridge: Cambridge University Press.

Patterson, Orlando

I987 The Emerging West Atlantic System: Migration, Culture and Underdevelopment in the United States and the Circum-Caribbean Region. In Population in an Interacting World, edited by William Alonso, 227-260. Cambridge, MA: Harvard University Press. 
Peattie, Mark R

I988 Nan'yō: The Rise and Fall of the Japanese in Micronesia, I885-I945. Pacific Islands Monograph Series, 4. Honolulu: Center for Pacific Islands Studies and University of Hawai'i Press.

Piore, Michael

I986 The Shifting Ground for Immigration. Annals of the American Academy of Political and Social Science 485 (May): 23-33.

Potts, Lydia

I990 The World Market for Labor Power: A History of Migration. London: Zed Books.

Quibria, M G

I996 Migration, Remittances and Trade: With Special Reference to Asian Developing Economies. In International Trade and Migration in the APEC Region, edited by P J Lloyd and L S Williams, 84-98. Oxford: Oxford University Press.

Reimers, David M

I983 An Unintended Reform: The 1965 Immigration Act and Third World Migration to the US. Journal of American Ethnic History 3:9-28.

Rod, Tess, and Lynne S Williams I996 Migration Intensification in the APEC Region: I98 I-I994. In International Trade and Migration in the APEC Region, edited by P J Lloyd and L S Williams, 32-48. Oxford: Oxford University Press.

Rodriguez, Nestor

I996 The Battle for the Border: Notes on Autonomous Migration, Transnational Communities, and the State. Social Justice 23 (3): 2 I-37.

Sassen, Saskia

I988 The Mobility of Labor and Capital: A Case Study in International Investment and Labor Flows. Cambridge: Cambridge University Press.

I996 Beyond Sovereignty: Immigration Policy Making Today. Social Justice $23(3): 9-20$.

Saywell, Trish

I997 Workers' Offensive. Far Eastern Economic Review, 29 May, 50-52. Hong Kong. Weekly.

Sharma, Nandita Rani

1997 Birds of Prey and Birds of Passage: The Movement of Capital and the Migration of Labor. Labour, Capital and Society 30 (I): 8-38.

Shimpo, M

I995 Indentured Migrants from Japan. In The Cambridge Survey of World Migration, edited by Robin Cohen, 48-50. Cambridge: Cambridge University Press.

Sider, G

1992 The Contradictions of Transnational Migration: A Discussion. In Towards a Transnational Perspective on Migration: Race, Class, Eth- 
nicity and Nationalism Reconsidered, edited by Nina G Schiller, Linda Basch, and Cristina Blanc-Szanton, 23I-240. New York: Annals of the New York Academy of Sciences.

Singhanetra-Renard, Anchalee

I992 The Mobilization of Labor Migrants in Thailand: Personal Links and Facilitating Networks. In International Migration Systems: A Global Approach, edited by Mary Kritz, L Lim, and Hania Zlotnic, I 50-I 76. Oxford: Clarendon Press.

Skeldon, Ronald

I994 Reluctant Exiles? Migration from Hong Kong and the New Chinese Overseas. New York: M E Sharpe.

I998 Migration Policies and National Security. In Redefining Security: Population Movements and National Security, edited by N Poku and D T Graham, 29-49. Westport, ст: Praeger.

Spaan, Ernst

I994 Taikongs and Calos: The Role of Middlemen and Brokers in Javanese International Migration. International Migration Review 28:93-I I3.

Subramani

I979 The Indo-Fijian Experience. St. Lucia: Queensland University Press.

Sudo, Ken'ichi

I997 Introduction: Contemporary Migration in Oceania. In Population Movement in the Modern World, volume I: Contemporary Migration in Oceania: Diaspora and Network, edited by Ken'ichi Sudo and S Yoshida, I-IO. Osaka: Japan Center for Area Studies.

Tinker, Hugh

I974 A New System of Slavery: The Export of Indian Labour Overseas, I830-I920. New York: Oxford University Press.

Torres, Carmela I

I996 Implications of International Migration on the Philippine Labor Market and Protection of Migrant Women. Asian Migrant 9 (2): 37-43.

UNPF, United Nations Population Fund I993 The State of the World Population. New York: UnPF.

Ward, R Gerard

I997 Expanding Worlds of Oceania: Implications of Migration. In Population Movement in the Modern World, volume I: Contemporary Migration in Oceania: Diaspora and Network, edited by Ken'ichi Sudo and S Yoshida, I79-I96. Osaka: Japan Center for Area Studies.

Warren, James Francis

I993 Ah Ku and Karayuki-san: Prostitution in Singapore 1870-1940. Singapore: Oxford University Press.

Willson, Margaret, Clive Moore, and Doug Munro

1990 Asian Workers in the Pacific. In Labor in the South Pacific, edited by Clive Moore, Jacqueline Leckie, and Doug Munro, 78-107. 


\section{Abstract}

Conventional wisdom seems to have it that the world has entered a "new age of migration" in which the international movement of labor is qualitatively and quantitatively distinct from the past. The dominant paradigm links labor movement to economic development, particularly for Asian migration, explaining migration in terms of differentials in labor demand and wages, while Pacific scholars have generally resorted to the particularities of Polynesian, Melanesian, and Micronesian cultures and island societies. This paper rejects these assumptions. We first describe the history of the Asia-Pacific migration system in three phases-the Age of Indenture, the Period of the Guest Worker, and the Era of Contract Labor Migration-establishing the scale and duration of flows and examining some of the mechanisms. We then review competing explanations of international migration, arguing that a key factor that economistic and essentialist explanations overlook is networks and institutions. We show how these are both reproduced and recreated in similar forms, and that transnational communities are almost inevitably the result.

KEYWORDS: Asian migration, indenture, international labor migration, migration networks, migration systems, overseas contract workers, Pacific Islands 